\title{
WHAT WE WANT THIS JOURNAL TO BE OUR FIRST EDITORIAL ESSAY IN WHICH WE HOPE TO START A CONTINUING AND EVOLVING CONVERSATION ABOUT WHY WE ARE NOW CREATING THIS NEW JOURNAL AND WHAT WE WANT IT TO BECOME
}

\author{
JAMES A. F. STONER* \\ Fordham University \\ New York, New York, U.S.A. \\ stoner@fordham.edu
}

Abstract. The primary purpose of this journal is to help all of us move more rapidly toward a sustainable and socially just world. We will seek to do so by providing a forum in which scholarship oriented toward sustainability and social justice, that is, toward building a better world for all, can be published and, we hope, influence all of us as scholars, managers, leaders, and citizens of the world to effect positive change. We, the editorial board, believe that this purpose is stable and we hope that our editors, contributors, and readers will be willing and eager to take risks, try out new ideas and types of analysis, insights, and approaches, learn from our experiences, and welcome changes in and evolution of the journal. It is clear that even the best informed and wisest among us has little certainty about how to manage for global sustainability. Humility thus is appropriate in all we write and do-but we seek to combine humility with intellectual rigour and professional boldness.

\footnotetext{
*This essay was written in collaboration with the members of the Editorial Board of the Journal of Management for Global Sustainability and is offered to our readers with the Board's concurrence.
} 


\section{DEFINITION OF GLOBAL SUSTAINABILITY}

There are multiple dimensions to and definitions of sustainability, sustainable development, and global sustainability. We have chosen to use the term global sustainability. We approach the task of communicating what we mean by that term in two ways. One way involves offering a one sentence definition of the phrase. In one sentence, our definition is:

Global sustainability is the broad set of interconnected issues that encompass, but are not limited to, achieving environmental conservation, social justice, poverty eradication, social entrepreneurship, desirable production and consumption patterns, species preservation, and spiritually rich lives.

The other way of communicating what we mean by the phrase global sustainability involves using the two sentence definition that follows. In two sentences, we define global sustainability as:

... a process that meets the needs of the present generation while enhancing the ability of future generations to meet their own needs. Global sustainability envisions a world that works for everyone with no one left out.

The two sentence definition offers separate statements to focus attention on two aspects of the concept of global sustainability. The first statement defines global sustainability as a process. The second statement looks at the concept as an aspiration. The first statement is a slight modification of the definition of sustainable development of the United Nations World Commission on Environment and Development, widely referred to as the Brundtland Commission (United Nations, 1987). The modified version of the Brundtland definition is:

Global sustainability is a process that meets the needs of the present generation while enhancing the ability of future generations to meet their own needs.

We use the word enhancing to emphasize the need for both a restorative mindset and for actions to undo the damage already done to the planet's capacity to support our species and many others.

Whereas that first phrasing speaks most clearly to the domain of inter-generational environmental and economic equity, the second phrasing of the concept calls attention more to social justice for present and future generations: 
Global sustainability involves the creation and maintenance of a world that works for everyone with no one left out.

This aspect of the definition is intended to call attention to such problems as global poverty, world hunger, social injustice, and the fact that at present the world does not work for billions of individuals. The world many of us currently inhabit is unjust and in need of healing now.

Hopefully, the term global sustainability reminds readers of the growing concern worldwide about species extinction, ocean acidification, fisheries exhaustion, aquifer, river, and ocean contamination, climate change, deforestation, and other aspects of a more and more likely impending ecosystem collapse. Unless these are addressed, the world we leave to our grandchildren may well be uninhabitable.

\section{A Commentary on the Use of the Word Global in the Phrase Global Sustainability}

We add the word global to the word sustainability for three reasons.

First, many of us have found that the words sustainable and sustainability are often interpreted in a narrow business context to be calling for continuing and unending business success, especially continuing business success in a business as usual (BAU) world, and sometimes as calling for sustainable competitive advantage. These framings represent neither the issues nor the intent we wish to address. We do recognize that commitments to global sustainability may well lead to continuing business survival and success in a world of not-business-as-usual (NBAU) and that such commitments may yield some substantive competitive advantages of greater or lesser duration. Both of these possibly desirable outcomes may accompany those commitments and they may be important reasons why some or many businesses make a commitment to global sustainability. They would, however, be fortunate by-products of the seeking of a much more important goal-the achieving of a socially just world that can enable our own and other species to thrive "forever" (in the sense John Ehrenfeld uses the word forever to imply "timelessness" and an "everlasting condition" [Ehrenfeld, 2010]).

Second, the word global hints at the perspective that for true sustainability to be achieved anywhere, it must be pretty well achieved everywhere. Some countries becoming completely sustainable in all they do, will not protect them and their citizens if others continue to pollute the planet and its atmosphere. In this endeavor, we all win together or we all lose together. 
Third, the word global also suggests the completeness with which we must align ourselves with the needs of a healthy planet and world society - global in the sense of everything we do: how we produce and consume, how we populate the earth, how we live our daily lives-global in the sense of whole and complete and everything, everywhere.

\section{OUR NUMBER ONE CRITERION FOR PUBLISHING ARTICLES}

In this framing, our number one criterion for acceptance of a submitted manuscript is a positive answer to the question: might reading the article based on this manuscript assist me, the reader, and others in contributing more effectively in moving toward a more sustainable world?

One way of thinking about how an article might provide this assistance is to determine whether it increases awareness, passion, and potential action (Rimanoczy, 2010). Our published articles may do so by:

1. Increasing awareness of the globally unsustainable nature of our world at this time. Awareness might include the problems and opportunities that situation creates, as well as the exciting and valuable things others are doing to improve our situation.

2. Building passion for taking action in the reader-passion about the seriousness of the situation as well as passion that calls us to action. Passion might include caring for others, energy for action, and a belief that useful actions are possible and within the realm of human possibility.

3. Providing ideas for ways to take original actions not yet initiated by others. Or an article might provide ideas for joining in on actions already being taken by others and/or building on those actions. For example, readers might use descriptions of actions by others as models for their own initiatives. They might also contact article authors and offer to assist them in efforts to continue to move forward.

\section{Implementation of these Thoughts in Reviewing}

One final question we will ask our reviewers before accepting a manuscript for publication is: Does the article answer the questions 1) "What's so?" 2) "So what?" and 3) "Now what?" That is, 
What's so? - does the article give the reader useful information about the situation we are in as that situation relates to some aspect of global unsustainability? Does it provide practical and accurate information? Does it support that information with appropriate references and citations? Can readers go to the original sources for the information to see if they agree with the information provided and can use it in creating their own initiatives?

So what?-does the article help the reader see constructive ways to understand and or interpret the situation described? Are the implications of "what's so" stated clearly? Does the article interpret the situation in a thoughtful and meaningful way? Of course, the editors may not agree with the interpretations and reasoning in the article, but would those interpretations and modes of reasoning be ones sensible readers would agree are logical and reasonable?

Now what? - does the article offer ideas about how the reader can take valuable and constructive action to improve the situation described/ interpreted/framed above? Are those ideas sensible and actionable? Are they described in enough detail that readers can, after adding their own creativity, actually do something potentially useful?

This final criterion, Now what?, may be the one that many authors will struggle with the most. Yet we believe that it may be the most valuable criterion.

\section{A Few Words on the Tone of the Journal's Voice}

The mantra of this journal is to repeat the premise that doing nothing is not an option.

That said, it may be useful early in the journal's life to admit to the following premises for the journal:

1. Many of us believe the situation "we" (our species, other living beings, and the ecosystems that support human civilization) are in is very, very serious.

2. We are convinced that doing nothing is essentially an assured path to a world in which we do not want and perhaps are unable to live.

3. It is often unclear what we should do. 
4. Despite this lack of clarity, action is necessary: we and others must do a great many things that seem reasonable and appear to make sense.

5. In many cases, we need to acknowledge that we cannot be certain a seemingly reasonable action will not turn out to be harmful rather than helpful, and so

6. when we do take action, we must accept that we will make mistakes. The uncertain nature of sustainability solutions means that all of us will make mistakes about what contributes to positive change.

7. Hopefully, in the full meaning of action-inquiry, we will all seek to learn from the successes and failures our actions yield.

\section{REFERENCES}

Ehrenfeld, J. 2010. Sustainability by design: A subversive strategy for transforming our consumer culture. New Haven: Yale University Press.

Rimanoczy, I. 2010. Business leaders committing to and fostering sustainability initiatives. Doctoral dissertation, New York: Columbia University Teachers' College.

United Nations. 1987. Report of the World Commission on Environment and Development: Our common future, http://www.un-documents.net/ our-common-future.pdf (accessed June 1, 2013). 